\title{
Government Policy on Water Resources Management
}

\author{
Dewi Tuti Muryati ${ }^{1}$ and Dharu Triasih ${ }^{2}$ \\ \{dewi.tuti@usm.ac.id, dharutriasih.fhusm@yahoo.co.id\} \\ ${ }^{1,2}$ Faculty of Law, Universitas Semarang, Semarang, Indonesia
}

\begin{abstract}
The government's policy on water resource management in Indonesia is about upholding the human and constitutional rights of every person to access water, as well as a means to realize sustainable development and environmentally friendly. According to this reason, it is the responsibility of the state to oversee the objectives of the management of water resources that can be achieved so that people's welfare can be realized. Because of this conception, this research carried out to examine the government's water resource management policy. This research is normative legal research with conceptual, statutory, and analytic approaches. Secondary data collection is carried out through legislation, literature studies, and analyzed qualitatively.
\end{abstract}

Keywords: water, management, policy.

\section{Introduction}

In 2002, an international meeting about sustainable development held in Johannesburg, World Summit on Sustainable Development (WSSD), encourages all countries by the end of 2005 to have had an IWRM plan and water efficiency strategy, as can be seen at Article 26 on Implementation Planning Meeting. The strategy aims to achieve sustainable development goals which include reducing poverty, food security, economic growth, protecting ecosystems, and addressing issues related to drought, flood, seizure of water, and sanitation [1].

The Legitimacy of the government of Indonesia in implementing the improvement and application of water is conveyed in Article 33 (3) of the 1945 National Constitution of Republic of Indonesia, include: "Land, water, and raw materials therein shall be managed by the government and used for the people's welfare". The regulation is a constitutional foundation in managing water.

The implementation of water management has not been able to meet the demands of society equally, while people who have the financial ability (both individuals and businesses) gain easy access to the water sources to gain an advantage. It happened because of rapid population growth and the increase in development activities, so that water demand is also increasing both in urban and rural areas [2].

Recognizing that national development activities on one side will contribute to improving the quality of life on people's welfare, but on the other hand, it also causes fear on the decline in the availability of raw materials, including water permanently in long term. Therefore, in the context of national development, especially in the field of raw materials (including water), required a law setting a clear and comprehensive in dealing with an extensive range of difficulties in managing water. This research focuses on: How does the government's policies in maintaining the water resource? 


\section{Data and Method}

This research is a normative legal research. Normative legal research is a research that gives a systematic explanation on an agreement that regulates a certain legal classification; scrutinizes the correlation between rules, legal principles, and legal doctrine. Reviewing the applicable laws and put on a certain legal problem [3]. The laws and regulations referred to water management. The approach used is a conceptual, statutory, and analytic approach. This legal approach used to learn, explore, and examine the policies applied to water management from a legal perspective.

The specification of this research is descriptive analytic which the results obtained in certain populations can be explained systematically, factually, and accurately [4]. This research will be describing the analysis result of government policies in water management.

The research data used is secondary data. The secondary data include primary and secondary legal material. Primary data used as follow:

1. The 1945 State Constitution of The Republic of Indonesia;

2. Indonesian State regulation No.11/1974 on Irrigation;

3. Indonesian State regulation No.7/2004 on Water Resources;

4. Indonesian State regulation No.17/2019 on Water Resources;

5. Indonesian Government Act No.121/ 2015 on Commercial Usage of Water;

6. Indonesian Government Act No.122/2015 on Potable Water Supply Network;

7. The Ruling of The Constitutional Court N0.85/PPU-XI/2013;

8. Circular Letter of The Minister of Public Works and Public Housing No.04/SE/2015 on the usage of water and collaboration between government and private enterprise;

9. Presidential Decree No.38/2015 on The Government Cooperation with Corporations about Providing Infrastructures;

10. Central Java Province Local Regulation No.3 of 2018 on Groundwater Management.

Secondary legal material is taken from literature books, journals, and relevant papers based on the issue of this research. The data analyzed with qualitative research with finding the laws and regulations and also library material. All the materials were presented in the description form.

\section{Result and Discussion}

The definition of the policy itself will be explained before the explanation of the water management policy. Etymologically, policy, or wisdom is the Indonesian translation of legal terms from Dutch language rechtspolitiek (recht and politiek) [5].

According to several authors, the definitions of policies were quite diverse. As noted by James E. Anderson that policy is: "A purposive course of action followed by an actor or set of actors in dealing with a problem or matter of concern". ("A series of measures has a specific purpose followed and implemented by an actor or group of actors to solve a specific problem"). Furthermore, Harold D. Lasswell and Abraham Kaplan gave the sense of policy as "a projected program of goals, values, and practices". ("A program to achieve the goals, values, and practices that targeted") [6].

The negligible difference from the opinions of Drupsteen, which gave the sense that the overall load policy goals and the means of specific actors. The policy is simply answer to a question about what was achieved by a person, through what way, and by what means it is implemented [7]. According to the opinion obtained that the policy contains an element of intent, goals and targets to be achieved or aspired. The word "policy" associated with "political policy", so it means a country planned to achieve specific goals aspired in the legal field.

Political law is "a legal policy to be applied or implemented nationally by a government of a particular country" or "basic policy of state officials in the areas of law which is continuously and derived from the values in society to achieve the aspired state". Mahfud MD states that "political law is the legal policy or law directory which will be enforced by the state to achieve the state's purpose; it could be making a new law and the replacement of the old law". Therefore, the politics of law should be based on the state's purpose and the legal system in the country 
concerned that the Indonesian context and purpose of the system is contained in the opening of The 1945 UUDNRI, especially Pancasila, which release the guiding principles of the law [8].

When it linked with water management, the meaning of water management policy is a policy of state or government that regulates the practices of managing water. This policy has specific goals and objectives as well as what the act of managing water has done to achieve the objectives and targets.

The policy of water management is also intimately related to laws (natural resources laws) because laws or regulations are an indicator of policy and simultaneously lay the groundwork for public policies [9]. According to the argument above, the policies of water management were made and implemented under laws or regulations.

The term "water management" is not regulated in Act No.11/1974, but in Article 1, item 6 knew as "water management system" it is every efforts to regulate the supervises such as ownership, control, management, use, exploitation, and control over water and its sources, including inorganic materials contained within, to achieve maximum benefits in fulfilling the lives and livelihood of the people. Further, it can be seen that in Article 1 paragraph 7 Act No.7/2004 on Water Resources, the term "water management" is an effort to strategize, implement, oversee and assess the application of water preservation, utilization of resources; water, and control of water damage"; then after being replaced by Act No.17/2019 on Water, the definition of the term "water management" does not change as stipulated in Article 1 paragraph 8 Act No.7/2004 on Water Resources.

In a general explanation of Act No.17/2019 on Water Resources Management mentioned that water management was organized based on the principle of public benefit, affordability, fairness, balance, independence, local wisdom, insight into the environment, conservation, sustainability, integrity and harmony, and transparency and accountability [10].

Subsequently explained that the management of water demands the development of an integrated system in a form of a national policy of water management, it should be implemented in strict principles and consequences from central to a local level.

The purposes of the regulation of water as defined in Article 3 Act No.17/2019 on Water Resources are as follows:

1. Providing protection and ensure that people gain of water;

2. Safeguard the sustainability of water availability and water to provide equitable benefits for society;

3. Guarantee the preservation of water and water to support sustainable development;

4. Ensuring the creation of legal certainty for the implementation of public participation in supervising the utilization of water from the planning, implementation, and evaluation of utilization;

5. Ensuring the protection and empowerment of communities, including indigenous peoples in the conservation of water and water sources; and

6. Controlling the destructive power of water that includes prevention, mitigation, and recovery.

Focused on Article 33 paragraph (2), (3), and (4) of 1945 UUDNRI and Presidential Decree No.33/2011 on National Policy of Water Resources Management can be seen that the state policy regarding water management contains aspects following:

1. Water management should provide protection and fulfillment of the rights of every people's access to water;

2. Water management is the responsibility of the state, on the right to control the state, the state makes the rules and policies of usage of water;

3. The welfare of the people became the philosophical and sociological basis for all the activities and management of water;

4. Water management must be sustainable and environmentally friendly; and

5. Their delegation further guidance on water management with the law. 
Therefore, if it associated with the objectives of water management to the fifth aspect, it can be seen that the policy of water management in Indonesia is in order to fulfill the rights of every people to access to water, as well as a means to achieve sustainable development and environmentally friendly. Therefore, the state is responsible for the escort of the purpose so that the setting of water management can be achieved and the people's welfare can be realized. For that reason, we need the support of legal instruments in the form of regulation regarding water which is able to realize the fulfillment of people's right to water.

The 1945 State Constitution of The Republic of Indonesia as the highest law in practice as the reference implementation of the state policy covers various aspects of both the legal, economic, political, social and other fields. One aspect that is regulated in The 1945 State Constitution of The Republic of Indonesia is about the soil, water, and raw materials contained therein as stated in the regulation of Article 33 (3) should be used for the welfare of the people. Based on this act, the regulations on soil, water, and raw materials in the regulation under the 1945 State Constitution of the Republic of Indonesia should also guarantee that it will be used for the welfare of the people.

The privilege to water is a fundamental right that has been guaranteed by The 1945 State Constitution of The Republic of Indonesia. As one of the fundamental rights, which is one of the human rights, the main state is compelled to respect, safeguard, and fulfill. In this context, the government established a policy relating to water management, with the hope that can protect to fulfill public interest for daily needs and other needs.

The presence of water as a source of community life, are naturally dynamic and flowing into the lower place without knowing the administrative borders. The presences of water following the hydrological cycle are closely related to weather conditions in an area, causing uneven water availability every time and every region. It requires water management is done in full from upstream to downstream with the river basin basis. Based on state control on the water, the central government and/or regional governments both provincial and district/city are given the duty and authority to regulate and manage water, including the responsibility to fulfill the daily minimum on the water needs in the community.

Emanated from the outcome of the research that has been done, the government has issued several policies on water management sector in the form of legislation, state regulations, local regulations, Presidential, and related regulations. Water management policy can be seen in some of laws and regulations as follows:

\section{a. Alegemeen Water Reglement 1936}

Before independence, the Dutch colonial government issued a regulation on water resources is Algemeen Water Reglement 1936 which is the principle of water management to support the culture plan. In these regulations contain water management policies, among others, the water group on the rainy season, pasten system of water irrigation (the allocation of water among the three commodities are grown in an area that is irrigated rice, and sugarcane), and scheduling of water distribution. The setting is more specifically regulated in Provinciale Water Reglement for Java and Madura as decentralization, which the government's tasks in the field of irrigation department submitted to the provincial level.

\section{b. The Regulation of The Republic of Indonesia No.11/1974 on Irrigation}

In the independence era, the political welfare of the colonial era to continue until the publication of the Regulation of the Republic of Indonesia No.11/1974 on Irrigation in lieu Algemeen Water Reglement 1936 which is considered inadequate to support development purposes. The irrigation laws in effect giving a wider scope than the Algemeen Water Reglement in 1936 and gave authority to the government in various dimensions of development and management in the field of irrigation include groundwater development and utilization of water for various purposes. Act irrigation consists of 17 chapters divided into 12 chapters consisting of (1) Definition, (2) Function, (3) Tenure and Privileges, (4) Planning and Technical Planning, 
(5) Development, (6) Concessions, (7) Exploitation and Maintenance, (8) Protection, (9) Financing (10) Criminal Provisions, (11) Transfer Policy (12) Final Provisions. Considering Act No.11/1974 on Irrigation limited to loading concept / philosophical foundation and does not regulate the substantive, the government issued Government Regulation No.22/1982 on Water Management and Irrigation, followed by the issuance of Government Regulation No.20/1990 on Water Pollution Control, Government Regulation No.27/1991 on the Swamp, and Government Regulation No.35/1991 on the River. In a third development of these regulations are still not able to meet the demand for water management arrangements are more complex problem, note that in all three of these government regulations do not refer directly to the agencies responsible for water management. To complement these deficiencies, then the government issued on Government Regulation No.82/2001 on managing water quality and water pollution control, which was followed by the issuance of Presidential Decree No.83/2002 on Management Coordination Team of Water Resources replace Presidential Decree No.123/2001 on Coordination Team for Water Resource Management.

\section{c. Regulation of the Republic of Indonesia No. 7 of 2004 on Water Resources}

Furthermore, it is known that on 18 March 2004, the government issued Act No.7/2004 on Water Resources is replaced by Act No.11/1974, on the basis that the rules on the water, either statute or regulations already inadequate to regulate the issue of water. The Act No.7/2004 on Water Resources was approved by the Parliament on 19 February 2004, which contains 18 chapters and 100 articles. Article 7 of Act No.7/2004 on Water Resources provides restrictions on water rights, include the privilege to use water and water exploitation rights. The water utilization cannot be leased or transferred either partially or entirely. Moreover, in Article 8 of Act No.7/2004 on Water Resources provides the privilege to use water attained without consent of the owner to fulfill day-to-day minimum needs for individuals and agricultural irrigation systems for farms owned by individuals. However, if the usage is done through altering the natural condition of water, to be used in large quantities, or to farm outside of the irrigation system, then it must get a permit issued by the appropriate government or local government authority. The implementing regulations of Act No.7/2004 on Water Resources include: The Government Regulation on Development of Water Supply System; Irrigation Implementation; Groundwater; Dams; River; Swamp and Right to Water.

The government on Act No.7/2004 has arranged for the management of water is not compartmentalized as one that integrates conservation, utilization and control of water damage. Water are managed by the state and used for the welfare of the people; therefore it is not enforced property rights but the rights to the water. Water rights with the understanding that only limited to the right to obtain and use or commercialize number (quota) of water in accordance with the allocation set by the government to water users, both of which must obtain a permit or not compulsory licenses.

The Act No.7/2004 on Water Resources is a lot of opposition from various parties for changing the function of the water of social objects into an economic object. The contradictory provisions are regulation including the operation of water and water rights. The articles related to the more emphasis on commercialization and privatization of water and eliminate the role of government as the party is obliged to manage water. Act No.7/2004 on Water Resource contained the domination and monopoly of water resource which opposite with the state's principle and used for the people's welfare as the constitutional mandate in Article 33 paragraph (2) The 1945 State Constitution of the Republic of Indonesia. The arrangements that give priority to commercial interests then trigger horizontal conflicts and eliminating the state's responsibility in meeting water needs.

\section{d. Constitutional Court Decision No.85 / PUU-X/2013}

On February 18, 2015, by the Constitutional Court Decision No.85/PUU-XI/2013, Act No.7/2004 on Water Resources has been canceled by the consideration that the policy of the law has not to warrant restriction of water management by private parties, so it is believed to be 
contradicting against the 1945 State Constitution of the Republic of Indonesia. Therefore to circumvent a legal vacuum, re-enacting the Constitutional Court Act No.11/1974 on Water until the establishment of the new legislation is the best course of action. In Constitutional Court's decision, there are four considerations in water management, as follows:

1) Correlation between the state, people, and water;

2) Guarantee basic rights to water in the regulation on Water;

3) Control over water by the state;

4) Restrictions on water utilization.

With the cancellation of Act No.7/2004 on Water Resources consequences to nonenforcement of regulations are The Government Regulation No.16 of 2005 on the Development of Water Supply System; No.20 of 2006 on irrigation; No.42 of 2008 on Management of Water Resources; No.43 of 2008 on Groundwater; No.38 of 2011 on the river; The Government Regulation No.73 of 2013 on the swamp.

According to the Constitutional Court judgment that water is a vital part of human life that governs the livelihood of the people, must be managed by the state (vide Article 33 (2) and (3) of The 1945 State Constitution of The Republic of Indonesia). Following these concerns, in utilizing water there must be very strict restrictions to maintain the endless supply of water for the prosperity of the nation (vide Article 33 paragraph (4) of The 1945 State Constitution of The Republic of Indonesia). The principal values are the following restrictions:

1) Every commercial use of water should not obstruct, override, and eliminate the people's right to water;

2) The state must fulfill people's privilege to have access to water;

3) Conserve the environment for continuity of water availability;

4) As an essential part of production which affects the livelihood of the people, water must be managed by the state and used for the welfare of the people, the surveillance and management by the state over water is absolute;

5) As an extension on the privileges to control the water by the state, and because water is an essential part for the livelihood of people, the top priority given for commercial use of water are State Owned Enterprises and Municipality Owned Corporations;

6) If all these limitations are met and there is still water availability, the government has the privilege to give the permit to private enterprises to commercially use the water with certain conditions and limitations.

The cancellation of Act No.7/2004 on Water Resources and the reintroduction of the Act No. 11/1974 on Water Resources by the Constitutional Court, then the Government issued Regulation Government Regulation No.121 of 2015 on Exploitation of Water Resources and Regulation Government Regulation No.122 of 2015 on Water Supply System set on December 28, 2015 were used as the legal basis for private companies managing water. In Article 59 of Government Regulation No. 121 of 2015 on Exploitation of Water Resources states that permit commercial use of water or licenses issued for commercial use in the surface water sectors and permit commercial use of groundwater that has been granted before the enactment of Government Regulation No.121 of 2015 on Exploitation of Water Resources, shall remain valid until the period of validity of the license expires.

Furthermore, the government issued two policies:

1) Circular of the Minister of Public Works and Public Housing No.04/SE/2015 on License to Use Water Resources and Contract Public Private Partnerships in Water Supply System Piping, to provide legal certainty for business license holders the use of water and the parties in the public private partnership contracts in the water supply system piping.

2) Presidential Regulation No.38 of 2015 concerning Government Cooperation with Business Entities in the Provision of Infrastructure, to deliver a clear legal basis for the growth of investment cooperation potable water supply system which is intended to raise the benefit for the people's welfare. 


\section{e. Regulation of the Republic of Indonesia No.23/2014 jo. Regional Government Act No. 9/2015 on the Second Amendment to Act No. 23/2014 on Regional Government}

Pursuant to the attachment of Act No.23/2014 on Regional Government as amended by Act No.9/2015, the law divided into government affairs in the field of energy and mineral resources. In geology, the Central Government has the matter in the determination of groundwater basins, the conservation zone of groundwater in groundwater basins cross provincial and cross country, protected areas of geology and geological heritage (geoheritage), status and early warning of the dangers of the volcano, status and advance warning of potential ground motion, balance resources and mineral and energy reserves nationwide, and the establishment of geological disaster-prone areas. While the Provincial Government has the determination affairs groundwater conservation zones in groundwater basin in the Province, the issuance of permits drilling, excavation permits, user licenses, and permits the exploitation of groundwater in the Province. The survey results revealed that the Government of Regency / City does not have governmental affairs division of the field of geology. It is known from the assertion in the Attachment Act No.23/2014 on Regional Government that groundwater extraction permits related to the affairs of the Provincial Government, while irrigating the fields located in the field of public works and arrangement of space.

The authority of local governments in managing water is decentralized authority from the center of the stricken area and for independently performing water management to be enjoyed by the whole society. It means that the water must maintain and preserve the upper watersheds and water catchment areas, so the quality and quantity of water is preserved. Furthermore, local governments conduct surveillance against employers who have been given permission to manage water, in order to manage not only prioritizes profit alone without any effort for preservation of the watershed. Similarly to the community, both individuals and businesses that utilize water without permission also must be done strictly controlling.

\section{f. Regulation of the Republic of Indonesia No.17/2019 on Water Resources}

On October $15^{\text {th }} 2019$, the President has approved Act No.17/2019 on Water Resources and entered into force on 16 October 2019. Act No.17/2019 on Water Resources repeal Act No.11/1974 on Water Resources and declared invalid. As for the consideration of the establishment of Act No.17/2019 on Water Resources is to address the imbalance between the availability of water that tend to decline and increasing water demand. Therefore, water needs to be managed with due regard to a social function, environment, and economy in harmony to achieve synergy and cohesion between regions, sectors, and between generations to fulfill the needs of the people on water. It is based on the understanding that water as part of water resources is an essential production branch and govern the livelihood of the people are managed by the state to be used for welfare of the people by the mandate of The 1945 State Constitution of the Republic of Indonesia. Act No.17/2019 on Water Resources is composed of 16 chapters and 79 chapters is the commitment of government and Parliament to assert state control over the meaning of the water. In the legislation emphasized that water is a public good and should be managed by the control and mastery of a strong state, therefore there are three policies:

1) The government has the broadest authority to control and exploit the water resources that will be distributed to the public by priority to meeting the basic needs of daily and agriculture.

2) Permission for use of water for the needs of the business by the private sector will be given after the people's needs are met and priority was given to the state, enterprises, BUMDes, Cooperative, and afterward to the private sector and individuals.

3) Paying for management cost according to the benefit gained are compulsory for beneficiaries of water management services, with the exception of the water for everyday basic needs, agricultural folk, and non-commercial use. 


\section{g. Indonesian Government Regulation No.43 of 2008 on Groundwater}

In setting the groundwater, it is known that the use of groundwater for various intentions (particularly regarding for the industrial sector), is the second choice when the water level is not sufficient, concerning the conservation, requirements include the prevention of environmental damage. Further in Government Regulation No.43 of 2008 regarding the Groundwater regulated control of water damage on the ground aimed at preventing, tackling saltwater intrusion, and restore the condition of groundwater due to saltwater intrusion, and to prevent, stop, or reduce the occurrence of land subsidence. Ground control of water damage done by controlling the extraction of the ground and increase the amount of groundwater recharge to prevent/reduce the rate of decline in groundwater levels.

\section{Conclusion}

The policy of water management in Indonesia is dynamic with several rounds of changes to the legislation which is caused by the demands to respond to the water crisis that occurred from time to time. The development of government policy in the water management is done through the issuance of legislation covering Act No.11/1974 on Water Resources and its implementing regulations, which are then replaced by Act No.7 of 2004 on Water Resources, the Constitutional Court ruling No.85/PUU-X/2013, which subsequently reinstated the Act No.11/1974 concerning irrigation equipped with Regulation implementing, and finally revoked Act No.11/1974 concerning irrigation with the enactment of Act No. 17/2019 on Water Resources.

Based on the situation above, it takes a development of water management policy that is more comprehensive, equitable, and instills democratic values for demanding arrangements that are truly able to protect the interests of the community. The government should immediately draw up the implementing regulations for water management and followed up by issuing regulations both at provincial and regency/city. Local governments should undertake the water management for the needs of everyday people in a professional manner.

\section{References}

[1] Article 26 of Johanesburg Declaration on Sustainable Development, 4 September 2002 [2] Silalahi,MD.Pengantar Hukum Sumber Daya Air dan Lingkungan Hidup di Indonesia.Alumni,Bandung,(2003)

[3] Soejono dan H.Abdurrahman,Metode Penelitian Hukum. Rineka Cipta. Jakarta, 2003

[4] Sunggono,Bambang.Metode Penelitian Hukum, Raja Grafindo Persada. Jakarta, 2003

[5] Termorshuizen,Marjanne.Kamus Hukum Belanda-Indonesia. Djambatan. Jakarta, 1999

[6] Islamy,Irfan. Prinsip-Prinsip Perumusan Kebijaksanaan Negara. Bumi Aksara.Jakarta,1991

[7]Rangkuti,Siti Sundari.Hukum Lingkungan dan Kebijaksanaan Lingkungan Nasional.Universitas AirlanggaPress.Surabaya,2000

[8] Mahfud,MD. Membangun Politik Hukum,Menegakkan Konstitusi. Pusaka LP3ES Indonesia. Jakarta,2006

[9] Singler,Jay A and Benjamin R. Beede. The Legal Source of Public Policy in Muhammad Akib. Hukum Lingkungan Perspektif Global dan Nasional. Raja Grafindo Persada.Jakarta,2014

[10] _ Undang-Undang Republik Indonesia No.17 Tahun 2019 tentang Sumber Daya Air. Sekretariat Negara Republik Indonesia, Jakarta, 2019 